\title{
НОРМАТИВНО-ПРАВОВЕ ЗАБЕЗПЕЧЕННЯ ЩОДО ОБЛІКУ ВИТРАТ НА ПОЛІПШЕННЯ ОСНОВНИХ ЗАСОБІВ
}

\author{
НОРМАТИВНО-ПРАВОВОЕ ОБЕСПЕЧЕНИЕ УЧЕТА ЗАТРАТ НА \\ УЛУЧШЕНИЕ ОСНОВНЫХ СРЕДСТВ
}

\section{REGULATORY SUPPORT COST ACCOUNTING FOR IMPROVEMENT OF FIXED ASSETS}

У статті досліджено $i$ проаналізовано нормативно-правове забезпечення та виділено розбіжності у фінансовому $і$ податковому обліку, щзо стосуються витрат на поліпшення основних засобів. Також визначено вимоги щзодо віднесення витрат на поліпшення основних засобів у бухгалтерському і податковому обліку. Досліджено, щзо від результатів обліку витрат на поліпшення основних засобів, залежить правильність визначення фінансового результату в бухгалтерському обліку та правильність визначення об'єкта оподаткування податком на прибуток, у чому, в першу чергу, зачікавлені власники та керівництво підприємства. Доведено, що правильна $i$ рачіональна організачія бухгалтерського обліку витрат на поліпшення об'єктів основних засобів має велике значення для забезпечення об'єктивного відображення на бухгалтерських рахунках зазначених витрат і облікової вартості поліпшених основних засобів. Висвітлено проблеми щуодо обліку витрат на поліпшення основних засобів в процесі адаптаџії Наџіональних положень бухгалтерського обліку до Міжнародних стандартів бухгалтерського обліку та досліджено методику обліку основних засобів, щчо зазнала суттєвих змін у результаті реформування системи обліку.

Ключові слова: нормативно-правове забезпечення, облік витрат на поліпшення основних засобів, бухгалтерський і податковий облік.

В статье исследовано и проанализировано нормативно-правовое обеспечение $u$ выделены различия в финансовом и налоговом учете, касаюшиеся расходов на улучшение основных средств. Также определены требования по отнесению расходов на улучшение основных средств в бухгалтерском и налоговом учете. Доказано, что от результатов учета расходов на улучшение основных средств, зависит правильность определения финансового результата в бухгалтерском учете и правильность определения объекта налогообложения налогом на прибыль, в чем, в первую очередь, заинтересованы владельць и руководство предприятия. Доказано, что правильная и рациональная организация бухгалтерского учета расходов на улучшение объектов основных средств имеет большое значение для обеспечения объективного отражения на бухгалтерских счетах указанных расходов и учетной стоимости улучшенных основных средств. Освещены проблемы по учету расходов на улучшение основных средств в прочессе адаптащии Начиональных положений бухгалтерского учета с Международными стандартами бухгалтерского учета, а также исследована методика учета основных средств, претерпевшая существенные изменения в результате реформирования системы учета. 
Ключевые слова: нормативно-правовое обеспечение, учет расходов на улучшение основных средств, бухгалтерский и налоговый учет.

This article explores and analyzes the regulatory and legal framework and identified differences in financial and tax accounting related expenses for the improvement of fixed assets. Also the requirements to assign costs to improve fixed assets accounting and tax accounting. Investigated that the outcome of cost accounting for fixed assets improvement depends correct definition of financial results in accounting and correct definition of taxable income, what primarily interested owners and management. It is proved that the correct and rational organization of accounting costs for improvement of fixed assets is important to provide objective accounts to reflect these costs and improved book value of fixed assets. The problems concerning cost accounting for fixed assets improvement in the adaptation of national accounting regulations to International Accounting Standards and studied method of fixed assets that has undergone significant changes as a result of reform of the accounting system.

Keywords: regulatory support, cost accounting for the improvement of fixed assets, accounting and tax accounting.

Вступ. Невід'ємною частиною майна будь-якого підприємства є основні засоби, без яких неможливе здійснення господарських процесів.

Перехід України на принципи і методи ведення бухгалтерського обліку і складання фінансової звітності відповідно до Міжнародних стандартів бухгалтерського обліку зумовив істотні зміни в порядку ведення бухгалтерського обліку основних засобів.

Економічні перетворення, які здійснюються в Україні протягом останніх років, спрямовані на реформування господарського механізму, адекватного ринковій економіці. Одним із важливих завдань, які стоять перед бухгалтерським обліком, є надання інформації про витрати на поліпшення основних засобів з метою ефективного управління виробничо-фінансовою діяльністю підприємства. Однак, якість такої інформації та об'єктивність іiі відображення у звітності останнім часом втрачають свою корисність для користувачів. Головною причиною такої ситуації $\epsilon$ слабка методична розробка нормативних документів, що регулюють облік витрат на поліпшення основних засобів, неврегульованість норм податкового законодавства, їх постійні зміни та стрімка адаптація Національних положень бухгалтерського обліку до Міжнародних стандартів бухгалтерського обліку.

Розгляду важливих аспектів нормативно-правового забезпечення обліку витрат на поліпшення основних засобів присвячено наукові праці багатьох авторів, а саме: С.Ф. Голова [9], Д.Р. Кетлетта, Г.І. Олеховича, Г. С. Павлової [10], В.В. Сопка [11], М.Г. Чумаченка, О.В.Чернецької [10], В.Г. Швеця [12] та ін. Огляд наукових праць дозволив констатувати, що означені питання залишаються у дискусійній площині і потребують подальшого вивчення.

Актуальність дослідження зумовлена тим, що у результаті реформування системи обліку суттєвих змін зазнала методика обліку основних засобів. Дослідження розбіжностей у фінансовому i податковому обліку, які 
стосуються витрат на поліпшення основних засобів, може виявити значні резерви підвищення ефективності їх використання, що i обумовлює актуальність, теоретичну і практичну значущість наукового дослідження.

Постановка завдання. Метою статті $є$ порівняння вимог щодо віднесення витрат на поліпшення основних засобів у бухгалтерському i податковому обліку. Поставлена мета зумовила вирішення основних завдань:

- дослідити і проаналізувати нормативно-правове забезпечення щодо обліку витрат на поліпшення основних засобів;

- виділити розбіжності у фінансовому і податковому обліку, які стосуються витрат на поліпшення основних засобів.

Методологія. Теоретичну та методологічну основою дослідження складають загальнонаукові та економічні методи: системно-структурного аналізу, аналогій, аналізу та синтезу. Дослідження грунтується на аналізі матеріалів законодавчого характеру, фактичного матеріалу, наукових працях українських та зарубіжних вчених.

Результати дослідження. Організація бухгалтерського обліку на підприємствах регламентується низкою законодавчих актів. Важливим $є$ Закон України «Про бухгалтерський облік і фінансову звітність в Україні». Цей закон визначає правові засади регулювання, організації, ведення бухгалтерського обліку та складання фінансової звітності в Україні. Згідно даного документу бухгалтерський облік $є$ обов'язковим видом обліку, який ведеться підприємствами, так як фінансова, податкова,статистична та інші види звітності, що використовують грошовий вимірник,грунтуються на даних бухгалтерського обліку. Питання організації бухгалтерського обліку на підприємстві, відповідальність за правильність його ведення несе власник або уповноважений орган, який здійснює керівництво підприємством відповідно до законодавства та установчих документів [1].

Термін «поліпшення основних засобів» з’явився в Законі України «Про оподаткування прибутку підприємств» №334/94-ВР від 28.12.1994p. [3].

Слід наголосити увагу на тому, що одним із проблемних питань в частині обліку витрат на поліпшення основних засобів $€$ його нормативно-правове регулювання. Основним нормативним документом 3 обліку експлуатації та вибуття основних засобів є Положення (стандарт) бухгалтерського обліку 7 (П(С)БО7) «Основні засоби»[7], яке визначає концептуальні основи формування у бухгалтерському обліку інформації про основні засоби підприємства та іiі розкриття у фінансовій звітності. Достовірність і повнота інформації в частині основних засобів забезпечується нормативними документами з бухгалтерського обліку на різних рівнях. Дані нормативні документи мають різний правовий статус, формуючи у загальному чотири рівні регулювання бухгалтерського обліку основних засобів, що подані на рис.1, де видно, що держава регулює лише деякі аспекти обліку витрат на поліпшення основних засобів, залишаючи при 
цьому широкий спектр варіативності, що надає можливість власникам обирати оптимальний альтернативний варіант, враховуючи специфіку суб'єкта господарювання, що забезпечить досягнення поставленої ними мети.

За міжнародними стандартами фінансової звітності (МСФЗ) порядок відображення витрат на поліпшення основних засобів та розкриття інформації про них у фінансовій звітності визначається МСФ3 16 «Основні засоби»[5]. Відповідно до п. 24 МСФЗ 16 «Основні засоби», наступні видатки, що пов'язані з об'єктом основних засобів і вже були визнані, повинні додаватись до балансової вартості цього активу, коли $є$ ймовірність, що майбутні економічні вигоди, які перевищують первісно оцінений рівень продуктивності існуючого активу, будуть надходити до підприємства.

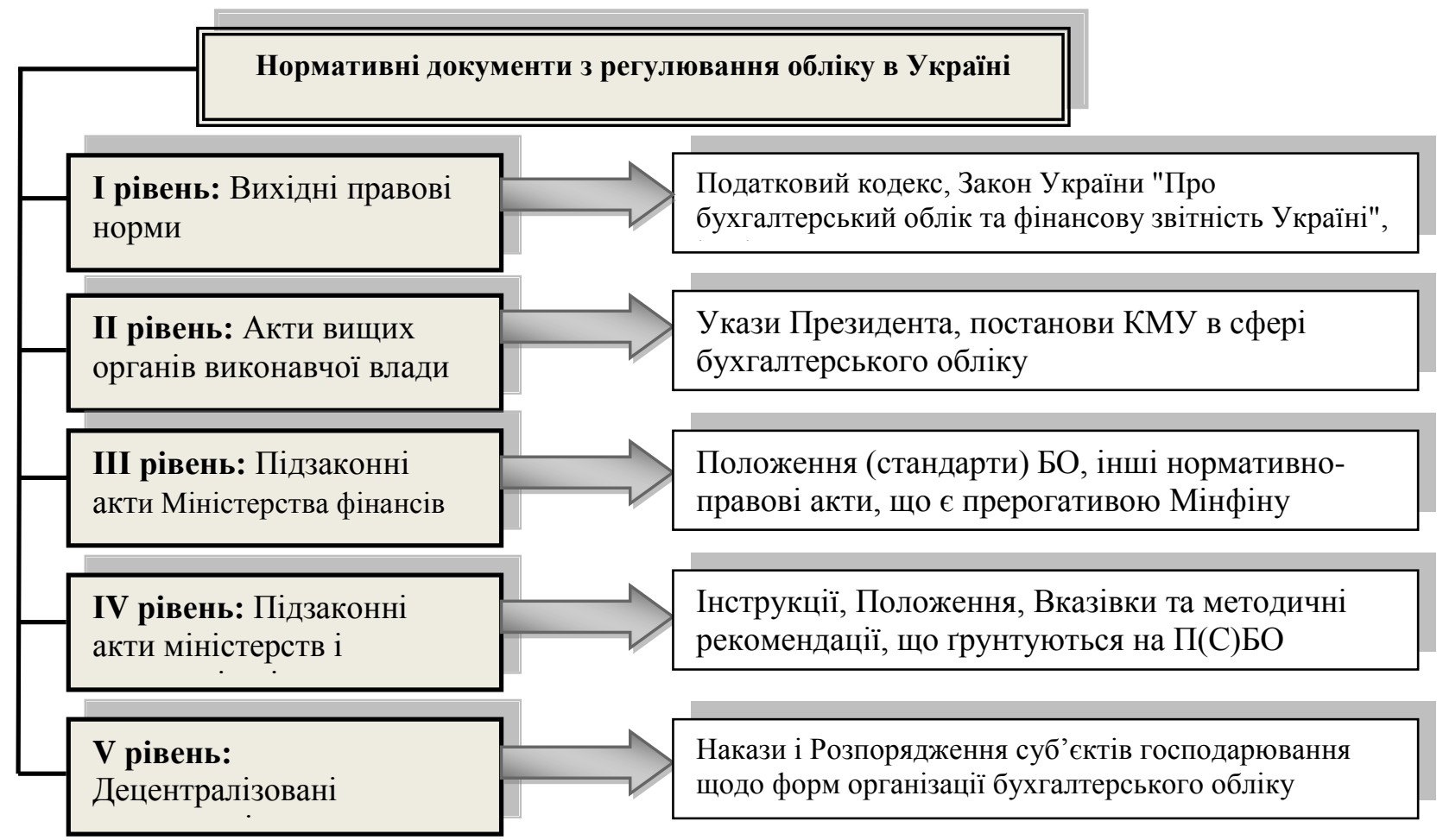

Рис. 1. Рівні законодавчого регулювання бухгалтерського обліку в Україні

Всі інші наступні видатки повинні визнаватись як витрати періоду, коли вони були понесені. У п. 25 МСФЗ 16 «Основні засоби» визначено, що наступні видатки на основні засоби визнаються як актив тільки тоді, коли вони поліпшують стан активу, підвищуючи оцінений спочатку рівень його продуктивності. До варіантів поліпшення, що ведуть до збільшення майбутніх економічних вигід, відносять: модифікацію об'єкта 3 метою подовження строку корисної експлуатації, включаючи збільшення його виробничої потужності; поновлення частин машин для досягнення значного поліпшення якості продукції, що випускається; упровадження нових 
виробничих процесів, що надають можливість значно зменшити оцінені спочатку операційні витрати. Видатки на ремонт та обслуговування основних засобів забезпечують відновлення або підтримання об'єкта в робочому стані. Оскільки в результаті їх здійснення не передбачено збільшення майбутніх економічних вигід, які підприємство може очікувати від оціненого спочатку рівня продуктивності активу, то вони здебільшого визнаються - як витрати періоду, коли були понесені. Порівняльний аналіз міжнародних, національних стандартів бухгалтерського обліку і фінансової звітності та податкового законодавства України виявив, що крім відсутності чіткого визначення поняття «поліпшення основних засобів», у кожному 3 розглянутих нормативно-правових актів є розбіжності у переліку видів такого поліпшення, що ускладнює обліковий процесс будь-якого підприємства (рис. 2). Таким чином, методологічні засади бухгалтерського обліку витрат на поліпшення та ремонт основних засобів встановлені Положенням (стандартом) бухгалтерського обліку 7, затвердженого наказом Міністерства фінансів України від 24.04.2000p. № 92 зі змінами та доповненнями, внесеними до нього згідно з наказами Міністерства фінансів України від 30.11.2000p. № 304 i від 25.11.2002p. № 989, а також Інструкцією про застосування плану рахунків бухгалтерського обліку № 291. Податковий облік витрат, пов’язаних iз поліпшенням основних засобів регламентується статтею 146 п.11 та п. 12 Податкового кодексу України[6].Однак у чинних нормативних документах ці питання відображені не повною мірою. Згідно П(С)БО 7 п.14 «Первісна вартість основних засобів збільшується на суму витрат, пов'язаних 3 поліпшенням об'єкта (модернізація, модифікація, добудова, дообладнання, реконструкція тощо), що приводить до збільшення майбутніх економічних вигод, первісно очікуваних від використання об'єкта».

Слід зауважити, що порядок відображення в бухгалтерському обліку витрат на поліпшення об'єктів основних засобів Інструкцією № 291 «Про застосування Плану рахунків бухгалтерського обліку активів, капіталу, зобов'язань і господарських операцій підприємств і організацій» [8]. на сьогоднішній день не регламентується. Проведені дослідження економічної літератури та практичний досвід засвідчує, що 3 метою раціональної організації синтетичного й аналітичного обліку названих витрат доцільно всі витрати, пов'язані з поліпшенням об'єктів основних засобів, відносити на рахунок 15 «Капітальні інвестиції». Для цього до даного рахунку необхідно відкрити додатковий субрахунок 156 «Витрати на поліпшення об’єктів основних засобів».

Наступним об’єктом обліку, на якому доцільно зупинитися, є облік витрат на ремонт (капітальний, поточний) основних засобів. Так, згідно 3 п. 15 П(С)БО 7 «Основні засоби»[7]: «Витрати, які здійснюються для підтримання об’єкта в робочому стані, що приводить до збільшення майбутніх 
економічних вигод, первісно очікуваних від використання об'єкта, включають в склад витрат». Таким чином, на суму витрат на проведення ремонту основних засобів вартість основних засобів не збільшується, а дана сума списується на витрати звітного періоду.

Відповідно до Податкового кодексу України п. 12 ст. 146 [6], платник податку має право, суму витрат, що пов'язані з ремонтом та поліпшенням об'єктів основних засобів, в тому числі орендованих або отриманих в концесію, у розмірі, що не перевищує 10 відсотків сукупної балансової вартості всіх груп основних засобів на початок такого звітного року віднести до витрат з метою оподаткування того звітного податкового періоду, в якому такі поліпшення або ремонт були здійснені.

Тому, платники податків, включаючи другий квартал 2012 року, відносили витрати на ремонт та поліпшення основних засобів в тому періоді в якому вони були здійснені. Нова редакція статті 146 п.12 із 1 липня 2012 року дещо змінила порядок віднесення витрат на ремонт та поліпшення основних засобів і виклала його наступним чином: «Сума витрат, що пов'язана 3 ремонтом та поліпшенням об'єктів основних засобів, в тому числі орендованих або отриманих в концесію, у розмірі, що не перевищує 10 відсотків сукупної балансової вартості всіх груп основних засобів на початок такого звітного року відноситься платником податку до складу витрат».

Це засвідчує той факт, що за податковими законами витрати на ремонт та поліпшення основних засобів в межах 10\% ліміту відносяться на витрати в період їх виникнення, а витрати понад ліміт збільшують первісну вартість основних засобів. Тобто, платник податків, навіть не очікуючи закінчення ремонту (поліпшення), має право лімітні витрати віднести до складу: виробничих, загальновиробничих, адміністративних, витрат на збут та інших операційних витрат. Але при ремонті (поліпшенні) виробничих та загальновиробничих основних засобів такі лімітні витрати прямо або шляхом розподілу загальновиробничих витрат формують собівартість реалізованих товарів, а основних засобів адміністративного призначення - адміністративні витрати. Спираючись на тлумачення податкового кодексу, бачимо, що податкова собівартість реалізованих товарів розраховується за правилами, ідентичними правилам бухгалтерського обліку (пп. 14.1.228 Податкового кодексу України)[6]. Розглядаючи правила включення ремонтнополіпшувальних витрат до собівартості, слід зауважити, що відповідно до П(С)БО 7 «Основні засоби», яким передбачено зовсім різні підходи до обліку витрат на ремонт та на поліпшення основних засобів. Витрати на ремонт 




Рис. 2. Види поліпшення основних засобів відповідно до норм чинного законодавства в Україні 
виробничих або загальновиробничих основних засобів повною сумою потрапляють до собівартості прямо (Дт 23) або через загальновиробничі витрати (Дт 91) за датою їх виникнення. Щодо витрат на поліпшення виробничих або загальновиробничих основних засобів, то П(С)БО 7 не дозволяє визнавати їх повною сумою у собівартості або загальновиробничих витратах, тобто списувати їх туди, минаючи амортизацію. Згідно п. 14 вищевказаного положення, витрати на поліпшення об'єктів основних засобів збільшують їх первісну вартість. Тобто, в бухгалтерському обліку такі витрати капіталізують і вони включаються у собівартість лише по мірі нарахування амортизації. Аналогічна ситуація складається із витратами на ремонт (поліпшення) основних засобів адміністративного призначення та витратами на основні засоби, пов'язаними із збутом продукції.

Підводячи підсумок, необхідно зосередити увагу на тому, що досліджені нормативно-правові документи визначають юридичний зміст процесів формування господарських операцій, створюють юридичну базу з обліку витрат на поліпшення основних засобів на підприємстві, і як наслідок необхідність організації ї бухгалтерського обліку. Таким чином, діюча нормативна база формує систему юридичних засад щодо бухгалтерського обліку витрат на поліпшення основних засобів на підприємстві. Стосовно стану законодавчої бази України слід вказати, що структура іï побудована таким чином, щоб охопити всі сфери господарювання та визначити основні принципи підприємницької діяльності. Інакше кажучи, чинні закони та нормативні акти спрямовуються на встановлення певних рамок та нормативів господарювання, які дозволяють кожному суб'єкту (підприємству або приватній особі) отримувати прибутки від своєї діяльності на засадах законності, економного використання ресурсів і виконання зобов'язань перед суспільством і державою. У разі недоотримання встановлених нормативів законодавством передбачені відповідні санкції.

Негативним аспектом, на нашу думку, є той факт, що до кожного нормативно-правового документу додається цілий перелік змін та доповнень, які необхідно відслідковувати і враховувати у практичній діяльності.

Висновки. Узагальнюючи вищевикладене, зауважимо, що облік витрат на поліпшення основних засобів $€$ складним процесом та має низку особливостей, що, головним чином, зумовлено новими вимогами податкового законодавства і специфічністю обліку операцій $з$ поліпшення основних засобів та їх впливом на оцінку вартості об’єктів.

Досліджено, що у податковому обліку на відміну від бухгалтерського, витрати на ремонтні роботи поділяються на утримання основних засобів (технічне обслуговування), а також ремонти та поліпшення основних засобів (реконструкція, модернізація та інші види поліпшень). Зрештою у податкових 
цілях до однієї групи потрапляють як поліпшення, так і всі ремонти незалежно від їхнього виду.

Таким чином, порядок організації та ведення бухгалтерського обліку витрат на поліпшення основних засобів сприятиме правильному й раціональному застосуванню на підприємствах i організаціях нормативноправових документів. Правильна і раціональна організація бухгалтерського обліку витрат на поліпшення об'єктів основних засобів має велике значення для забезпечення об'єктивного відображення на бухгалтерських рахунках зазначених витрат і облікової вартості поліпшених основних засобів, а також для одержання необхідних даних для розкриття інформації про основні засоби в Примітках до фінансової звітності підприємства. Від результатів обліку витрат на поліпшення основних засобів, залежить правильність визначення фінансового результату в бухгалтерському обліку та правильність визначення об'єкта оподаткування податком на прибуток, у чому, в першу чергу, зацікавлені власники та керівництво підприємства.

У ході подальшого дослідження будуть вивчатися проблеми щодо обліку і оподаткування витрат на ремонт та поліпшення основних засобів 3 урахуванням змін у нормативно-правових документах.

\section{Література:}

1. Закон України «Про бухгалтерський облік і фінансову звітність в Україні» від 16.07.99 p. № 996-XIV // Режим доступу: http://zakon.rada.gov.ua.

2. Методичні рекомендації з бухгалтерського обліку основних засобів, затверджені наказом Міністерства фінансів України від 30.09.2003 р. № 561 // Нормативно-правове забезпечення бухгалтерського обліку в Україні. - К.: ННЦ "IАЕ", 2012. - 636 с. - С. 483-495.

3. Закон України «Про оподаткування прибутку підприємств», 28.12.1994p., №334/94-BР, із змінами і доповненнями. - Режим доступу: http:// zakon.rada.gov.ua/.

4. Наказ Міністерства фінансів України „Про затвердження Методичних рекомендацій з бухгалтерського обліку основних засобів” № 561 від 30.09.2003. - Режим доступу: http:// zakon.rada.gov.ua/.

5. МСФ3 16 «Основні засоби» [Електронний ресурс] / Верховна Рада України. Режим доступу : http://www.zakon.rada.kiev.ua.

6. Податковий кодекс України від 02.12.2010 p. № 2755-VI (із змінами та доповненнями від 20.09.2011 р.) [Електронний ресурс]. - Режим доступу: http://zakon2.rada.gov.ua/laws/show/2755-17.

7. Положення (стандарт) бухгалтерського обліку 7 «Основні засоби». Затверджено наказом Міністерства фінансів України № 92 від 27 квіт. 2000 р. [Електронний ресурс] / Верховна Рада України. - Режим доступу : http://www.zakon.rada.gov.ua.

8. Наказ Мінфіну України від 30.11.1999 р. № 291 « Про затвердження Плану рахунків бухгалтерського обліку та Інструкції про його застосування»

9. Голов С.Ф., Костюченко В.М. Бухгалтерський облік за міжнародними стандартами: Практичний посібник./ С.Ф. Голов, В.М. Костюченко. - К.: Лібра, 2001. - 354 c. 
10. Павлова Г.С., Чернецька О.В. Фінансовий облік активів аграрних підприємств: навч.посібник / Г.С.Павлова, О.В. Чернецька // MOНМС України, Дніпропетр.держ.аграр.ун-т. - Донецьк: Юго-Восток, 2012. - 392 с.

11. Сопко В.В. Бухгалтерський облік в управлінні підприємством: навч.посібник / В.В.Сопко. - К.: КНЕУ, 2006. - 526 с.

12. Швець В.Г. Теорія бухгалтерського обліку:- 3-тє вид., перероб. і доп. / В.Г. Швець. - К.: Знання, 2008. - 535 с.

\section{References:}

1. Law of Ukraine «On a record-keeping and financial reporting in Ukraine» from 16.07.99 1 996-xiv // access Mode: http://zakon.rada.gov.ua.

2. Methodical recommendations from the record-keeping of the fixed assets, ratified the order of Ministry of finance of Ukraine from 30.09.2003 № 561 // Normatively legal providing of record-keeping in Ukraine. - K.: NNC "IAE", 2012. - 636 s. - S. 483-495.

3. Law of Ukraine «On taxation of income of enterprises», 28.12.1994r., № 334/94-VR, with changes and additions. it is access Mode: http:// zakon.rada.gov.ua/.

4. An order of Ministry of finance of Ukraine is „About claim of Methodical recommendations from the record-keeping of the fixed assets” № 561 from 30.09.2003. is access Mode: http:// zakon.rada.gov.ua/.

5. MSFZ 16 the «Fixed assets» [Electronic resource] / Verkhovna Rada of Ukraine. it is access Mode : http://www.zakon.rada.kiev.ua.

6. There is an internal revenue code of Ukraine from 02.12.2010 № 2755-vi (with changes and additions from 20.09.2011) [Electronic resource]. it is access Mode: http://zakon2.rada.gov.ua/laws/show/2755-17.

7. Position (standard) of record-keeping 7 the «Fixed assets». Zatverdzheno nakazom of Ministry of finance of Ukraine № 92 from 27 kvit. in 2000 [Elektronniy resurs] / Verkhovna Rada of Ukraine. it is access Mode : http://www.zakon.rada.gov.ua.

8. There is an order of Minfinu of Ukraine from 30.11.1999 № 291 « About claim of Card of accounts of record-keeping and Instruction about his application»

9. Golov S.F., Kostyuchenko V.M. Record-keeping after international standards: Practical manual./ S.F. Golov, V.M. Kostyuchenko. - K.: Libra, 2001. - 354 s.

10. Pavlova H.Ye. Chernets'ka O.V Finansovyy oblik aktyviv ahrarnykh pidpryyemstv: navch.posibnyk / H.Ye.Pavlova, O.V. Chernets'ka // MONMS Ukrayiny, Dnipropetr.derzh.ahrar.un-t. - Donets'k: Yuho-Vostok, 2012. - 392 s.

11. Sopko V.V. record-keeping in a management an enterprise: navch.posibnik / V.V.Sopko. - K.: KNEU, 2006. - 526 s.

12. Shvec' V.G.. Theory of book-keeping obliku:- 3-te kind., pererob. and dop. / V.G. Shvec'. - K.: of Knowledge, 2008. - 535 s. 